\title{
Mutation screening of the SMARCA3 gene in Swedish colorectal cancer patients
}

\author{
TATJANA DJUREINOVIC, SIMONE PICELLI, ANTONIA KALUSHKOVA, ANNIKA LINDBLOM \\ and THE SWEDISH LOW-RISK COLORECTAL CANCER GROUP
}

Department of Molecular Medicine and Surgery, Karolinska Institute, Stockholm, Sweden

Received November 15, 2007; Accepted December 19, 2007

\begin{abstract}
The SMARCA3 gene was recently found to be a common target for methylation in colon and gastric cancer, suggesting it has possible tumor suppressor activity. To determine whether SMARCA3 plays a role in colorectal and/or gastric cancer predisposition, a mutation screening of the gene was performed in affected index cases from 20 Swedish families with colorectal and/or gastric cancer. Notably, one family included in the screening exhibited suggestive linkage to the region on chromosome $3 \mathrm{q}$ that harbors the SMARCA3 gene. In addition to known polymorphisms, nine novel variants - none of them clearly pathogenic - were detected. Seven of these variants were further tested in an additional 287 patients with a family history of the disease, but their frequency was found to not be significantly different from that observed in the controls. In conclusion, although a very low effect of some variants could not be excluded, it seems that the SMARCA3 gene does not play an important role in the predisposition to colorectal and gastric cancer.
\end{abstract}

\section{Introduction}

Colorectal cancer (CRC) is one of the most common types of malignancies worldwide and has an estimated genetic contribution of approximately $35 \%$ (1). A small fraction of CRC cases are found in the setting of highly penetrant inherited syndromes, such as familial adenomatous polyposis (FAP), hereditary nonpolyposis colorectal cancer (HNPCC) and MUTYH-associated polyposis (MAP); however, a significant proportion of CRC families remain in which no predisposing genes have so far been identified (2).

Similarly to $\mathrm{CRC}$, multiple factors play a role in gastric carcinogenesis $(1,3,4)$. Gastric cancer frequently occurs in families affected with HNPCC and FAP, particularly in families of Asian origin (2). In addition, an increased predisposition

Correspondence to: Dr Tatjana Djureinovic, Present address: Department of Genetics, Microbiology and Toxicology, Stockholm University, Svante Arrhenius väg 16E, Room E425, SE-106 91 Stockholm, Sweden

E-mail: tatjana.djureinovic@gmt.su.se

Key words: SMARCA3, colorectal cancer, gastric cancer to gastric cancer has been observed in the Peutz-Jegher (5), Li-Fraumeni (6) and Ataxia Telangiectasia (7) syndromes. The majority of families with an autosomal dominant predisposition to gastric cancer, outside the syndromes mentioned above, have a diffuse type of gastric cancer. In a subset of these families, germline mutations in the E-cadherin $(\mathrm{CDH} 1)$ gene have been identified (8).

The SWI/SNF-related, matrix-associated, actin-dependent regulator of chromatin, subfamily a, member 3 (SMARCA3) gene (also known as helicase-like transcription factor $H T L F$ ) is a member of the SWI/SNF family of genes highly conserved in eukaryotes. The SWI/SNF complex is a multiprotein complex involved in chromatin remodeling in an ATP-dependent manner and is implicated in a variety of important cellular functions. Some members of this family, such as SMARCA3, also have sequence-specific domains and can be targeted directly to specific promoters (9). A growing body of evidence suggests that subunits of this complex may be involved in cancer development (10). In particular, mutations in several of the SWI/SNF family genes (RAD54B, hSNF5/INII, BRGl) have been reported in different tumors and tumor cell lines, suggesting a potential tumor suppressor activity for this gene family (11-15). Moreover, the SMARCA3 gene has been shown to be a common target for methylation and epigenetic silencing in colon and gastric cancer (16-19).

In the search for novel CRC predisposing genes, a genomewide scan in 18 non-HNPCC/non-FAP CRC families from Sweden was recently performed (20). In this analysis, suggestive linkage of the disease to chromosome 3q22.1-26.31 was identified in family 242, with the highest location score of 1.99 for the marker D3S1279. In this 3-generation family, an autosomal dominant inheritance of gastric and rectal cancer was observed. Notably, the region of linkage on chromosome 3 harbors the SMARCA3 gene.

In an attempt to evaluate the role of the SMARCA3 gene in Swedish CRC patients, mutation screening of all exons, the $5^{\prime}$ and $3^{\prime}$ untranslated regions (UTR) and a putative promoter region was carried out.

\section{Materials and methods}

Patients. Family 242 was included in the previously-performed genome-wide linkage analysis. Three family members presented with gastric cancer and six with rectal cancer, while five family members presented with adenomas and/or hyperplastic polyps. Two affected members from family 242 , one 
with gastric cancer (Co-441) and one with rectal cancer (Co-666), as well as index cases from 20 additional colorectal and/or gastric cancer families, were selected for mutation screening of the SMARCA3 gene. Of these 20 additional families, 18 had a history of both colorectal and gastric cancer, while two had a history of gastric cancer only.

The frequency of the identified variants was subsequently analysed in a set of 287 unrelated patients, index cases of families with at least two family members affected with CRC. Of these 287 patients, 95 had also reported at least one gastric cancer case in the family. The variant frequency was also assessed in a control population of either 95, 380 or 475 anonymous blood donors from the Stockholm region.

All patients were recruited from the Cancer Family Clinic at Karolinska Hospital. Family history was obtained, and all diagnoses were confirmed through medical records or death certificates. None of the patients included in the study had classical or attenuated polyposis. HNPCC was excluded based on family history of the disease, microsatellite instability test or mutation screening of the mismatch repair genes. In addition, mutation screening of the $C D H 1$ gene was performed in families 24 and 242, and no mutations were detected (unpublished data). Informed consent was obtained from each subject in accordance with the Swedish law concerning the ethical approval of research on human subjects (97/205, 00/291, 03/198).

DNA from all individuals was extracted from peripheral blood lymphocytes using the standard phenol/chloroform extraction method. In addition, total RNA was extracted from EBV-transformed lymphocytes from two members of family 242 (Co-634 and Co-666) using the TRIzol RNA Extraction Kit (Life Technologies Inc., Rockville, MD, USA) as per the manufacturer's protocol.

\section{Mutation analysis of SMARCA3}

Mutation screening of the SMARCA3 gene. All exons, including the exon/intron boundaries, the 5' and 3'UTR regions and the putative promoter sequence, were amplified by PCR using the primers listed in Table I. PCR amplifications were carried out in a $25-\mu 1$ reaction mixture containing $50 \mathrm{ng}$ genomic DNA, 20 pmol of each primer, $100 \mu \mathrm{M}$ dNTPs, $1 \mathrm{X}$ PCR buffer II (Applied Biosystems, Foster City, CA), $1.5 \mathrm{mM}$ $\mathrm{MgCl}_{2}$ and $0.5 \mathrm{U}$ AmpliTaq Gold DNA Polymerase (Applied Biosystems). PCR reactions were in general carried out using a Touchdown PCR program with an initial annealing temperature of $58^{\circ} \mathrm{C}$. However, exons 2, 6, 7, 13, 21 and 25, as well as the UTR regions, were amplified at an initial annealing temperature of $62^{\circ} \mathrm{C}$ in order to avoid non-specific PCR amplification. PCR conditions were $95^{\circ} \mathrm{C}$ for $9 \mathrm{~min}$ and $30 \mathrm{sec}$, 7 cycles at $95^{\circ} \mathrm{C}$ for $45 \mathrm{sec}, 58^{\circ} \mathrm{C}$ for $45 \mathrm{sec}\left(-1^{\circ} \mathrm{C} /\right.$ cycle $)$ and $72^{\circ} \mathrm{C}$ for $45 \mathrm{sec}$, followed by a further 29 cycles of $95^{\circ} \mathrm{C}$ for $30 \mathrm{sec}, 51^{\circ} \mathrm{C}$ for $45 \mathrm{sec}$ and $72^{\circ} \mathrm{C}$ for $45 \mathrm{sec}$, and a final $72^{\circ} \mathrm{C}$ for $7 \mathrm{~min}$. Amplified PCR products were cleaned prior to sequencing by the addition of $1 \mu 1$ ExoSap-IT Clean-up Kit (GE Healthcare) to $5 \mu 1 \mathrm{PCR}$ product, followed by incubation at $37^{\circ} \mathrm{C}$ for $30 \mathrm{~min}$ and enzyme inactivation at $80^{\circ} \mathrm{C}$ for $15 \mathrm{~min}$. One microliter of cleaned PCR product was used as a template for a $10-\mu 1$ sequencing reaction using the ABI Big Dye Terminator v3.1 Kit (Applied Biosystems) according to the manufacturer's instructions. The sequencing reaction products were subsequently precipitated with EDTA and ethanol following the manufacturer's guidelines. Prior to sequencing, $10 \mu \mathrm{l}$ of Hi-Di Formamide was added to the dried pellets, and samples were electrophoresed in an ABI 3730 XL capillary sequencer (Applied Biosystems). The Chromas program version 1.43 (http://trishul.sci.gu.edu.au/ $\sim$ conor/chromas.html) was used for sequence analysis.

$R T-P C R$ analysis. RT-PCR was carried out using the two available RNA samples from family 242 isolated from EBVtransformed lymphocytes (Co-634 and Co-666). cDNA was prepared using the GeneAmp RNA PCR Kit (Applied Biosystems) employing the random hexamer priming method. SMARCA3 cDNA was amplified in two fragments with fragment one spanning exons 1-14 and fragment two spanning exons 14-25. Primers for both fragments were designed so that at least one of them was covering two exons (primer sequences are shown in Table I). RT-PCR amplifications were carried out using the same PCR protocol as that used for the amplification of each exon. A Touchdown PCR program was used for amplification with an initial annealing temperature of $62^{\circ} \mathrm{C}$. Amplified RT-PCR products were size fractionated on an agarose gel along with the control sample.

SNuPE analysis. The allelic difference in mRNA expression in one member of family 242 (Co-666) was tested using the Single Nucleotide Primer Extension (SNuPE) analysis. For this purpose, the coding polymorphism c.909G $>$ A located in exon 8 was used. Fragments used as templates in the SNuPE reaction were a 367-bp RT-PCR product containing exon 8 (primers are shown in Table I) and the amplification product from genomic DNA amplified using the same primers as those used in the mutation screening of exon 8 . The SNuPE reaction was carried out in reverse orientation using fluorescentlylabeled primer: 5'-ATGGAAGTTGGTAAGGATTA-3'. The reaction mixture of $20 \mu \mathrm{l}$ contained $\sim 50 \mathrm{ng}$ of template, $50 \mu \mathrm{M}$ ddCTP, $50 \mu \mathrm{M}$ dATP, $50 \mu \mathrm{M}$ dGTP, $50 \mu \mathrm{M}$ dTTP, $0.025 \mu \mathrm{M}$ primer, 0.6 units Thermo Sequenase, together with the buffer provided by the manufacturer (Amersham Life Science). PCR conditions were as follows: $95^{\circ} \mathrm{C}$ for $2 \mathrm{~min}, 30$ cycles at $95^{\circ} \mathrm{C}$ for $30 \mathrm{sec}, 55^{\circ} \mathrm{C}$ for $30 \mathrm{sec}$ and $72^{\circ} \mathrm{C}$ for $1 \mathrm{~min}$, followed by a final $72^{\circ} \mathrm{C}$ for $10 \mathrm{~min}$. The reaction products were size fractionated on an ABI PRISM 377 DNA sequencer using $10 \%$ denaturing polyacrylamide gel, and the allelic ratios were calculated using the GeneScan $3.1^{\circledR}$ software program.

Southern blot analysis. For Southern blot analysis, $\sim 10 \mu \mathrm{g}$ genomic DNA from patient Co-666 was digested with $B g l I I$ and blotted to a positively charged Nylon Plus Membrane (Qiabrane) using standard protocols. The membrane was hybridized with two probes; one 1.3-kb probe spanning exons 1-14 and the second 1.4-kb probe spanning exons 14-25 of the SMARCA3 gene. Both probes were prepared by RT-PCR and labeled with $\alpha^{32} \mathrm{P}-\mathrm{dCTP}$. Hybridization was performed using standard conditions.

\section{Results and Discussion}

In total, 15 germline sequence variants were detected in the initial mutation screening of the SMARCA3 gene in 21 patients (Tables II and III). Six of these 15 variants were reported in 
Table I. Primers used for mutation screening of the SMARCA3 gene.

\begin{tabular}{|c|c|c|}
\hline Fragment & Forward & Reverse \\
\hline Promoter 1 & gggacagagcaagactccat & ctccacggtttacgagacct \\
\hline Promoter 2 & catgcatacgctgaggctta & gcactaggaaagcccaatca \\
\hline 5'UTR & ccctccettctgtgctctgact & tgagtgggatgacaagagga \\
\hline Exon 1 & ggctcgaaaacgatcca & ggaaggtcaggttcatttgg \\
\hline Exon 2 & gagaaaactactcatatggtctttgg & ttctcttattttctaggttaa \\
\hline Exon 3 & ggaaatcccagataaagtataacaaag & agccctaacaagttcaaagat \\
\hline Exon 4 & ttctttcaagtctgcccaac & gccttgagcacaaattagcc \\
\hline Exon 5 & tgagccacagcacccag & aagaccacaaatacccacacg \\
\hline Exons 6 and 7 & cctggcccgtttgacattaac & aagatagtaagatctagtccc \\
\hline Exon 8 & ttttctggtgaactgggtttc & gaaaacacaatttcttg \\
\hline Exon 9 & ttattcaccetcccettcag & tcaatcatctccttcatgaaa \\
\hline Exon 10 & aaaccaaggttttaagagggataatac & cgtgccagcetctatctc \\
\hline Exons 11 and 12 & gcttttagcagatctgac & tttaaaacccatggttagctc \\
\hline Exon 13 & tgtactctagcacaggagataatttga & gaaaatgcaccaaaaggaaaa \\
\hline Exon 14 & cacattattgccatctcctta & ccccaatgaatgactctttaa \\
\hline Exon 15 & ttggatttgtcacactactgcc & aaagcctgaattttggaacac \\
\hline Exon 16 & agcagtttgtgcttcagttt & ggggcagaatttacacccac \\
\hline Exon 17 & ttgggccaaatagatactcttactg & aagtgccaactggttcaagc \\
\hline Exon 18 & tgttctgtttcgttcttcttgg & ttcagtgaatgggaaacaaag \\
\hline Exon 19 & agatctctcttggttttattagagttg & aagcaatctccatttgacaga \\
\hline Exon 20 & gactttccetactggcaagc & ttaaatccaagtgcaaaactc \\
\hline Exon 21 & cagatgtctcttaaatggatgaaatc & catttcccetcaaattcacc \\
\hline Exon 22 & gggaaataacatttcaggacc & taaaattcttgtgctgccagg \\
\hline Exon 23 & cctgaatttatcagaaaatgac & ttctaaagtttgcctaagaattttcac \\
\hline Exon 24 & tgcaaaacactgaaagatcagg & ttcatgcattacttgcttaattg \\
\hline Exon 25 & attgcggtttttgccattag & caggccacagtatataacggaac \\
\hline 3'UTR-1 & tgaacctatttttaatgaaacttcaaa & gcctctcactcccacagact \\
\hline 3'UTR-2 & gttcacataaatgacttggagtttt & ggagtcaacccaaattctgc \\
\hline 3'UTR-3 & tttgaacttgagtaattcatcctt & tgtaatgettgatctaccagg \\
\hline 3'UTR-4 & agacctttctgcagggatga & tatggcaccgaggaaggtaa \\
\hline RT-frag 1 & ccatgtcctggatgttcaag & ctgcaagctccettttc \\
\hline RT-frag 2 & ccgctttctgtgttaagcaa & tcctttacaatgaattttgtgatga \\
\hline SNUP-RNA & attctgggaacagcgaaatg & gcgggagctagacaattctg \\
\hline
\end{tabular}

the single nucleotide polymorphism (SNP) database (http:// www.ncbi.nlm.nih.gov/SNP) and their frequency, identified among 21 patients in this study, was similar to the reported frequency. These variants were therefore considered to be polymorphisms (Table II). For the nine variants not reported in the SNP database, a heterozygote frequency was determined by testing control individuals (Table II).

None of the identified sequence variants were clearly pathogenic. However, for seven novel variants a slightly increased frequency was observed in the patients compared to the controls. To estimate the significance of these variants, their frequency was determined in a set of 287 unrelated patients with a family history of CRC, 95 of whom also had a family history of gastric cancer. No significant difference was observed in the frequency of the variants between the patients and the controls, either in the entire group or in the group of 95 patients with a history of both colorectal and gastric cancer (Table II). The frequency among patients was only slightly higher for the $\mathrm{c} .2440 \mathrm{C}>\mathrm{T}$ variant $(\mathrm{p}=0.12 ; \mathrm{OR}=2.39 ; 95 \% \mathrm{CI}$ 0.75-7.61) located within exon 21. The Pro814Ser amino acid change caused by c. $2440 \mathrm{C}>\mathrm{T}$ was predicted to be possibly damaging using the PolyPhen program (http://coot.embl.de/ PolyPhen/) with a PSIC score difference of 1.800 . The c. $2440 \mathrm{C}>\mathrm{T}$ sequence variant was found in nine patients, two from the set of 20 families and seven from the second set of 287 patients. However, in only three of these nine families were additional samples available for segregation analysis (family 89 , family 106 , and family 258 ), and a possible co- 
Table II. Sequence alterations observed in the SMARCA3 gene.

\begin{tabular}{|c|c|c|c|c|c|c|}
\hline \multirow[b]{2}{*}{ Location } & \multirow[b]{2}{*}{$\begin{array}{l}\text { Nucleotide } \\
\text { change }\end{array}$} & \multirow[b]{2}{*}{$\begin{array}{l}\text { Amino acid } \\
\text { change }\end{array}$} & \multicolumn{3}{|c|}{ Carrier frequency ${ }^{\mathrm{a}}$} & \multirow[b]{2}{*}{ Status $^{b}$} \\
\hline & & & $\begin{array}{l}\% \text { First set } \\
\text { of patients }\end{array}$ & $\begin{array}{c}\% \text { Second set } \\
\text { of patients }\end{array}$ & $\%$ Controls & \\
\hline Promoter & $-454 \mathrm{G}>\mathrm{A}$ & & $5(1 / 22)$ & $0.38 \quad(1 / 261)$ & $0 \quad(0 / 367)$ & Novel \\
\hline Promoter & $-291 \mathrm{C}>\mathrm{T}$ & & $5(1 / 22)$ & $0 \quad(0 / 261)$ & $0 \quad(0 / 366)$ & Novel \\
\hline Intron 6 & IVS6-24C $>\mathrm{T}$ & & $9(2 / 22)$ & $2.14(5 / 234)$ & $1.58(7 / 444)$ & Novel \\
\hline Exon 8 & c. $909 \mathrm{G}>\mathrm{A}$ & T303T & $50(11 / 22)$ & & $38^{\mathrm{c}}$ & Reported \\
\hline Exon 8 & c. $932 A>G$ & N311S & $5(1 / 22)$ & & $2^{c}$ & Reported \\
\hline Intron 12 & IVS12+56C>T & & $5(1 / 22)$ & $1.95(5 / 256)$ & $1.49(5 / 336)$ & Novel \\
\hline Exon 16 & c. $1740 \mathrm{~A}>\mathrm{G}$ & R580R & $14(3 / 22)$ & & $11 \quad(9 / 80)$ & Novel \\
\hline Exon 20 & c. $2328 \mathrm{~A}>\mathrm{G}$ & A776A & $40 \quad(9 / 22)$ & & $37^{c}$ & Reported \\
\hline Exon 21 & c. $2411 \mathrm{~T}>\mathrm{C}$ & I804T & $5(1 / 22)$ & $0.38 \quad(1 / 260)$ & $0.92(4 / 437)$ & Novel \\
\hline Exon 21 & c. $2440 \mathrm{C}>\mathrm{T}$ & P814S & $9(2 / 22)$ & $2.69(7 / 260)$ & $1.14(5 / 437)$ & Novel \\
\hline Exon 21 & c. $2456 \mathrm{G}>\mathrm{A}$ & $\mathrm{R} 819 \mathrm{H}$ & $5(1 / 22)$ & $3.85(10 / 260)$ & $5.95(26 / 437)$ and $5^{c}$ & Reported \\
\hline 3'UTR & c. $3416 \mathrm{~A}>\mathrm{G}$ & & $50(11 / 22)$ & & $44^{c}$ & Reported \\
\hline 3'UTR & c.3538insTA & & $5(1 / 22)$ & $0 \quad(0 / 274)$ & $0.3(1 / 335)$ & Novel \\
\hline 3'UTR & c. $4657 \mathrm{~A}>\mathrm{G}$ & & $50(11 / 22)$ & & $42(39 / 89)$ and $42^{c}$ & Reported \\
\hline 3'UTR & c. 4775 insGAC & & $40 \quad(9 / 22)$ & & $53(47 / 89)$ & Novel \\
\hline
\end{tabular}

${ }^{a}$ Heterozygotes. ${ }^{b}$ Novel variants or variants reported in the single nucleotide polymorphism database. ${ }^{c}$ Average estimated heterozygosity reported in the SNP database.

Table III. Variants identified in the patients.

\begin{tabular}{|c|c|c|}
\hline Family & Patient & Variants \\
\hline 12 & Co- 89 & c. $909 \mathrm{G}>\mathrm{A}$, c. $3416 \mathrm{~A}>\mathrm{G}, \mathrm{c} .4775 \mathrm{insGAC}$ \\
\hline 24 & Co-166 & $-291 \mathrm{C}>\mathrm{T}$, c $.909 \mathrm{G}>\mathrm{A}$, c $.3416 \mathrm{~A}>\mathrm{G}, \mathrm{c} .4775 \mathrm{insGAC}$ \\
\hline 26 & Co-135 & c. $909 \mathrm{~A}$, c $.2328 \mathrm{~A}>\mathrm{G}$, c. $3416 \mathrm{~A}>\mathrm{G}$, c $.4657 \mathrm{~A}>\mathrm{G}$, c $.4775 \mathrm{insGAC}$ \\
\hline 81 & Co-207 & c. $909 \mathrm{~A}$, c. $2328 \mathrm{G}$, c. $2411 \mathrm{~T}>\mathrm{C}$, c. $4657 \mathrm{G}$ \\
\hline 242 & Co-441 & c. $909 \mathrm{G}>\mathrm{A}, \mathrm{c} .3416 \mathrm{~A}>\mathrm{G}$ \\
\hline 242 & Co-666 & c. $909 \mathrm{G}>\mathrm{A}$, c $.2328 \mathrm{~A}>\mathrm{G}$, c $.4657 \mathrm{~A}>\mathrm{G}$ \\
\hline 293 & $\mathrm{Co}-772$ & c. $909 \mathrm{~A}, \mathrm{IVS} 9+78 \mathrm{G}>\mathrm{T}$, c. $3416 \mathrm{~A}$ \\
\hline 303 & Co-762 & c. $909 \mathrm{G}>\mathrm{A}$, c $.2328 \mathrm{~A}>\mathrm{G}$, c. $2440 \mathrm{C}>\mathrm{T}$, c. $3416 \mathrm{~A}$, c $.4657 \mathrm{~A}>\mathrm{G}$ \\
\hline 398 & Co-1124 & c. $909 \mathrm{~A}$, c $.1740 \mathrm{~A}>\mathrm{G}$, c $.2328 \mathrm{~A}>\mathrm{G}, \mathrm{c} 3416 \mathrm{~A}>\mathrm{G}, \mathrm{c} .4657 \mathrm{~A}>\mathrm{G}, \mathrm{c} .4775 \mathrm{insGAC}$ \\
\hline 436 & Co-1107 & $-454 \mathrm{G}>\mathrm{A}, \mathrm{c} 909 \mathrm{~A}$, c $.2328 \mathrm{~A}>\mathrm{G}, \mathrm{c} 3416 \mathrm{~A}>\mathrm{G}, \mathrm{c} .4657 \mathrm{~A}>\mathrm{G}$ \\
\hline 485 & Co-1315 & c. $909 \mathrm{G}>\mathrm{A}$, c $.2456 \mathrm{G}>\mathrm{A}$, c. $3416 \mathrm{~A}$ \\
\hline 488 & $7 / 03$ & с. $909 \mathrm{~A}$, c $.932 \mathrm{~A}>\mathrm{G}$, c $.1740 \mathrm{~A}>\mathrm{G}$, c. $2328 \mathrm{~A}>\mathrm{G}$, c $.3416 \mathrm{~A}>\mathrm{G}$, c.3538insTA, c.4657A $>\mathrm{G}$, c $.4775 \mathrm{insGAC}$ \\
\hline 506 & $45 / 04$ & IVS6-24C > T, c.909G >A, c.3416A, c.4657A $>\mathrm{G}$ \\
\hline 550 & $443 / 04$ & c. $909 \mathrm{~A}, \mathrm{IVS} 12+56 \mathrm{C}>\mathrm{T}, \mathrm{c} .3416 \mathrm{~A}$ \\
\hline 552 & $349 / 04$ & c. $909 \mathrm{G}>\mathrm{A}$, c. $3416 \mathrm{~A}>\mathrm{G}, \mathrm{c} .4775 \mathrm{insGAC}$ \\
\hline 569 & Co-1296 & c. $909 \mathrm{~A}$, c. $3416 \mathrm{~A}>\mathrm{G}$, c $.4657 \mathrm{~A}>\mathrm{G}$, c $.4775 \mathrm{insGAC}$ \\
\hline 578 & $531 / 04$ & c.909A, c. $1740 \mathrm{~A}>\mathrm{G}$, c. $3416 \mathrm{G}$, homozygous c. 4775 insGAC \\
\hline 590 & $593 / 04$ & c. $909 \mathrm{G}>\mathrm{A}$, c. $3416 \mathrm{~A}>\mathrm{G}$, c $.4775 \mathrm{insGAC}$ \\
\hline 600 & $601 / 04$ & c. $909 \mathrm{~A}$, c $.2328 \mathrm{~A}>\mathrm{G}$, c. $3416 \mathrm{~A}>\mathrm{G}$, c $.4657 \mathrm{~A}>\mathrm{G}$, c $.4775 \mathrm{insGAC}$ \\
\hline 615 & $525 / 04$ & c. $909 \mathrm{G}>\mathrm{A}$, c $.2328 \mathrm{AG}$, c. $2440 \mathrm{C}>\mathrm{T}$, c $.3416 \mathrm{~A}$, c $.4657 \mathrm{~A}>\mathrm{G}$ \\
\hline 677 & $687 / 04$ & IVS6-24C >T, c.909A \\
\hline
\end{tabular}


segregation of the variant with the disease was observed in family 258 only. Although this variant most probably represents a rare polymorphism, the possibility that it might act as a low risk or modifying variant could not be excluded.

Two identified promoter variants were not found among the tested control individuals. The variant $-454 \mathrm{G}>\mathrm{A}$ was detected in a total of 2 patients, one from the first set of 20 families screened and the second among the set of 287 patients. Due to the lack of additional DNA material from these two families, segregation analysis of this variant could not be determined. The variant $-291 \mathrm{G}>\mathrm{A}$ was found only in one patient, Co-166, from family 24 . However, subsequent segregation analysis performed in this family showed no co-segregation of $291 \mathrm{G}>\mathrm{A}$ with the disease. Both promoter variants need to be tested in a larger sample of DNA material in order to evaluate their role in colorectal and gastric cancer predisposition.

Family 242 was included in the recently-performed genome-wide linkage analysis in CRC families (20), and was shown to be possibly linked to the region on chromosome 3q22.1-26.31 which harbors SMARCA3. Two members from family 242 , one affected with rectal cancer and one with gastric cancer, were selected for mutation screening of the gene. Altogether, four variants were identified in these two family members (c.909G >A, c.2328A $>$ G, c.3416A $>$ G, c.4657A>G) (Table III). However, only the silent variant c.909G $>$ A was shared by both family members. Furthermore, RT-PCR, SNuPE and Southern blot analyses excluded the SMARCA3 gene as the disease-causing gene in this family as no abnormalities were detected.

The methylation of $\mathrm{CpG}$ regions is known to cause the silencing of a number of tumor suppressor genes. Therefore, the identification of genes whose promoters are common targets for methylation may point to their possible role as tumor suppressor genes. Moinova et al first reported SMARCA3 promoter methylation in $43 \%$ of primary colon cancers and $26 \%$ of colon cancer cell lines. It was also suggested that loss of expression of SMARCA3 confers a growth advantage in some colon cancers (16). Moreover, promoter methylation of this gene was found in primary gastric cancer and gastric cancer cell lines (17-19), as well as in oesophageal cancer (18).

Only one mutation in SMARCA3 has been reported previously. A hemizygous nonsense mutation at codon 979 was found in one colon cancer cell line matched to the primary tumor (16). The present data suggest that obviously pathogenic mutations in SMARCA3 are rare and may be poorly tolerated. The discovery of gene silencing caused by promoter hypermethylation rather than mutations found in tumors also suggests that this gene plays a more important role in tumor progression than tumor initiation.

To the best of our knowledge, this is the first report on screening for germline mutations in the SMARCA3 gene. The lack of clearly pathogenic mutations suggests that SMARCA3 is not a common target for mutations in familial colorectal and gastric cancer. In addition to known polymorphisms reported in the SNP database, nine novel variants were also detected. All identified variants demonstrated similar frequencies in patients and controls; however, their significance remains to be determined by future studies.

The region of linkage identified in family 242 spans $43 \mathrm{cM}$ and contains close to 200 genes. Evaluation of candidate genes within a region of this size is beyond the scope of this study; however, the confirmation of the linkage in an independent family sample of DNA material with the same phenotype would be of great importance as it would help in narrowing down the region and reducing the number of candidate genes. Recently, novel evidence for a CRC predisposing locus on chromosome 3q21-q24 has been provided (21). There is therefore a need to combine the results of the two studies and determine the candidate CRC predisposing genes.

\section{Acknowledgements}

This study was supported by The Cancer and Allergy Foundation, The Gustav V Jubileé Foundation, The Nilson-Ehle Foundation, The FoU Foundation, The Swedish Research Council and The Swedish Cancer Society. The following are members of the Swedish Low-Risk Colorectal Cancer Group: Johan Dalén, David Edler, Fredrik Hjern, Jörn Holm, Martin Janson, Claes Lenander, Ulrik Lindforss, Nils Lundqvist, Hans Olivecrona, Louise Olsson, Lars Påhlman, Jörgen Rutegård, Kennet Smedh and Anders Törnqvist. The contributions of the authors are as follows: T.D. designed the study, performed DNA sequencing and data analysis and drafted the manuscript. S.P. and A.K. helped in the DNA sequencing. A.L. participated in the design and coordination of the study and helped to draft the manuscript. All authors read and approved the final version of the manuscript.

\section{References}

1. Lichtenstein P, Holm NV, Verkasalo PK, Iliadou A, Kaprio J, Koskenvuo M, Pukkala E, Skytthe A and Hemminki K: Environmental and heritable factors in the causation of cancer analyses of cohorts of twins from Sweden, Denmark, and Finland. N Engl J Med 343: 78-85, 2000.

2. Lynch HT and De la Chapelle A: Hereditary colorectal cancer. N Engl J Med 348: 919-932, 2003.

3. Ekstrom AM, Serafini M, Nyren O, Hansson LE, Ye W and Wolk A: Dietary antioxidant intake and the risk of cardia cancer and noncardia cancer of the intestinal and diffuse types: a population-based case-control study in Sweden. Int J Cancer 87: 133-140, 2000.

4. Wu AH, Crabtree JE, Bernstein L, Hawtin P, Cockburn M, Tseng CC and Forman D: Role of Helicobacter pylori CagA ${ }^{+}$ strains and risk of adenocarcinoma of the stomach and esophagus. Int J Cancer 103: 815-821, 2003.

5. Giardiello FM, Brensinger JD, Tersmette AC, Goodman SN, Petersen GM, Booker SV, Cruz-Correa $M$ and Offerhaus JA: Very high risk of cancer in familial Peutz-Jeghers syndrome. Gastroenterology 119: 1447-1453, 2000.

6. Kim IJ, Kang HC, Shin Y, Park HW, Jang SG, Han SY, Lim SK, Lee MR, Chang HJ, Ku JL, et al: A TP53-truncating germline mutation (E287X) in a family with characteristics of both hereditary diffuse gastric cancer and Li-Fraumeni syndrome. J Hum Genet 49: 591-595, 2004.

7. Massad M, Uthman S, Obeid S and Majjar F: Ataxiatelangiectasia and stomach cancer. Am J Gastroenterol 85: 630-631, 1990.

8. Guilford P, Hopkins J, Harraway J, McLeod M, McLeod N, Harawira P, Taite H, Scoular R, Miller A and Reeve AE: E-cadherin germline mutations in familial gastric cancer. Nature 392: 402-405, 1998 .

9. Ding H, Benotmane AM, Suske G, Collen D and Belayew A: Functional interactions between $\mathrm{Sp} 1$ or Sp3 and the helicaselike transcription factor mediate basal expression from the human plasminogen activator inhibitor-1 gene. J Biol Chem 274: 19573-19580, 1999.

10. Klochendler-Yeivin A, Muchardt C and Yaniv M: SWI/SNF chromatin remodeling and cancer. Curr Opin Genet Dev 12: 73-79, 2002. 
11. Hiramoto T, Nakanishi T, Sumiyoshi T, Fukuda T, Matsuura S, Tauchi H, Komatsu K, Shibasaki Y, Inui H, Watatani M, et al: Mutations of a novel human RAD54 homologue, RAD54B, in primary cancer. Oncogene 18: 3422-3426, 1999.

12. Schmitz U, Mueller W, Weber M, Sevenet N, Delattre O and von Deimling A: INI1 mutations in meningiomas at a potential hotspot in exon 9. Br J Cancer 84: 199-201, 2001.

13. Versteege I, Sevenet N, Lange J, Rousseau-Merck MF, Ambros P, Handgretinger R, Aurias A and Delattre O: Truncating mutations of hSNF5/INI1 in aggressive paediatric cancer. Nature 394: 203-206, 1998.

14. Yuge M, Nagai H, Uchida T, Murate T, Hayashi Y, Hotta T, Saito $\mathrm{H}$ and Kinoshita T: HSNF5/INI1 gene mutations in lymphoid malignancy. Cancer Genet Cytogenet 122: 37-42, 2000.

15. Wong AK, Shanahan F, Chen Y, Lian L, Ha P, Hendricks K, Ghaffari S, Iliev D, Penn B, Woodland AM, et al: BRG1, a component of the SWI-SNF complex, is mutated in multiple human tumor cell lines. Cancer Res 60: 6171-6177, 2000.

16. Moinova HR, Chen WD, Shen L, Smiraglia D, Olechnowicz J, Ravi L, Kasturi L, Myeroff L, Plass C, Parsons R, et al: HLTF gene silencing in human colon cancer. Proc Natl Acad Sci USA 99: 4562-4567, 2002.
17. Leung WK, Yu J, Bai AH, Chan MW, Chan KK, To KF, Chan FK, Ng EK, Chung SC and Sung JJ: Inactivation of helicase-like transcription factor by promoter hypermethylation in human gastric cancer. Mol Carcinog 37: 91-97, 2003.

18. Hibi K, Nakayama H, Kanyama Y, Kodera Y, Ito K, Akiyama S and Nakao A: Methylation pattern of HLTF gene in digestive tract cancers. Int J Cancer 104: 433-436, 2003.

19. Hamai Y, Oue N, Mitani Y, Nakayama H, Ito R, Matsusaki K, Yoshida K, Toge T and Yasui W: DNA hypermethylation and histone hypoacetylation of the HLTF gene are associated with reduced expression in gastric carcinoma. Cancer Sci 94: 692-698, 2003.

20. Djureinovic T, Skoglund J, Vandrovcova J, Zhou XL, Kalushkova A, Iselius L and Lindblom A: A genome wide linkage analysis in Swedish families with hereditary nonfamilial adenomatous polyposis/non-hereditary non-polyposis colorectal cancer. Gut 55: 362-366, 2006.

21. Kemp Z, Carvajal-Carmona L, Spain S, et al: Evidence for a colorectal cancer susceptibility locus on chromosome 3q21-q24 from a high-density SNP genome-wide linkage scan. Human Mol Genet 15: 2903-2913, 2006. 